Henry Bacon

\section{KOHTI VERTAILEVAA TYYLITUTKIMUSTA}

Tyylin analyysi on jo pitkään ollut yksi elokuvatutkimuksen keskeisimpiä suuntauksia. Tässä artikkelissa tavoitteenani on nostaa keskusteluun, mitkä elokuvailmaisun parametrit ovat mitattavissa, luokiteltavissa ja laskettavissa, missä määrin näin saadut kvantitatiiviset tulokset vaativat täydennyksekseen kontekstualisointia, kuvailua ja tulkintaa sekä mitkä tyylilliset ulottuvuudet ovat lähtökohtaisesti analysoitavissa vain kvalitatiivisin menetelmin. Tältä pohjalta luonnostelen paitsi tyylin tutkimuksen protokollaa, luon myös pohjaa vertailevalle tutkimukselle. Näitä menetelmiä tarvitaan selvitettäessä, miten muualta tulleet vaikutteet on otettu haltuun jossakin tuotannollisessa kontekstissa.

Useilla humanistisilla ja sosiologisilla tutkimusaloilla harjoitetaan vertailevaksi luonnehdittavaa tutkimusta eli teosten, tapausten tai niistä muodostuvien kokonaisuuksien välisten yhtäläisyyksien ja erojen analyysiä ja tulkintaa. Kokonaisuudet voivat olla vaikka kansallisia elokuvakulttuureita eri aikoina tai niistä kehkeytyneitä ylikansallisia suuntauksia. Nämä ovat yleensä enemmän tai vähemmän heterogeenisiä, ja vertaileva tutkimus voi kohdistua myös niiden sisäisen koherenssin ja moninaisuuden välisen jännitteen analysoimiseen. Vertaileva analyysi on tarpeen kaikkinaisen historiallisen tutkimuksen kannalta: milloin ja miksi on tapahtunut muutoksia vaikkapa elokuvan tyylissä jossakin tuotannollisessa kontekstissa ja minkälaiset vaikutteet ovat sen saaneet aikaan. Vertailussa on huomioitava yleiset historialliset, ideologiset ja taloudelliset tekijät, jotka osaltaan ehdollistavat vaikutteiden leviämistä ja vastaanottoa. Vertaileva tutkimus on siis tyypillisesti monitieteistä, joskin kysymyksenasettelusta riippuen on mahdollista keskittyä erityiskysymyksiin. Esimerkiksi transnationaalissa elokuvatutkimuksessa fokusoidaan elokuvallisten vaikutteiden leviämiseen yli kansallisten rajojen. Analysoimalla ja yhdistämällä perinteisiä sekä aivan viime aikoina kehitettyjä metodeja ja lähestymistapoja tässä rakennetaan alustava malli taksonomiasta ja protokollasta, joiden avulla voidaan tehdä mahdollisimman vertailukelpoista tyylitutkimusta.

Vertailevan tutkimuksen tekeminen on mahdollista, kun tutkittavat aineistot ovat jollakin tapaa yhteismitallisia ja siten vertailukelpoisia. Tämä edellyttää systematiikkaa, joka tarjoaa ainakin jonkinasteisen objektiivisen
Henry Bacon, FT, professori Elokuva- ja televisiotutkimus, Helsingin yliopisto
KOLLEGIALT GRANSKAD

PEER-REVIEWED 
pohjan vertailulle, vaikka tutkimuksen kohteet tai edes niiden relevantit piirteet eivät olisi täysin redusoitavissa mitattavissa oleviin parametreihin. Elokuvatutkimuksessa ollaan tässä suhteessa hedelmällisessä tilanteessa. Parin-kolmen viime vuosikymmenen aikana elokuvallisen tyylin analyysiä varten on kehitetty vahvoja metodeja tyylillisten keinojen ja niiden adaptaation analysoimiseksi, mikä mahdollistaa vertailevan tyylintutkimuksen kehittelemisen aikaisempaa objektiivisemmalta pohjalta. Varsinkin David Bordwell historiallisessa poetiikassaan ja Kristin Thompson neoformalismissaan ovat luoneet käsitteistöä, joka mahdollistaa sen kohottamisen impressionistisen vaikutelmien kuvaamisen yläpuolelle. Vielä perusteellisempaa metodiikkaa elokuvan tyylitutkimukselle ovat luoneet Barry Saltin pikkutarkka analyysi elokuvan mitattavissa olevista ominaisuuksista ja ennen kaikkea lähinnä Yuri Tsivianin johdolla toteutettu Cinemetrics-verkkotyökalun käyttöönotto. Jälkimmäiseen kuuluu olennaisesti tietopankki, johon on jo nyt tallennettu paljon tietoa elokuvien otospituuksista ja niiden vaihteluista sekä kuvakoista ja niiden jakautumisesta kunkin elokuvan keston myötä. Korpus on jo niin suuri, että on mahdollista tehdä ainakin keskeisimmiltä elokuvan historian osilta perusteltuja yleistyksiä vaihteluista näiden parametrien suhteen.

Mitattavissa, luokiteltavissa ja laskettavissa olevien parametrien analyysi ja erilaisten tyylillisten keinojen edellyttämien teknisten keinovarojen kartoittaminen eivät kuitenkaan riitä kattavan tyylillisen analyysin tekemiseen. Tyylin arvioimiseen kuuluu väistämättä myös kontekstualisointi, kuvailu ja tulkinta: miksi on käytetty tiettyjä keinoja ja minkälaisen vaikutelman ne synnyttävät. Kuten John Gibbs ja Douglas Pye (2005) ovat korostaneet, on vastattava kysymykseen siitä, kuinka tyylilliset valinnat osallistuvat merkityksen muodostukseen ja siten ohjaavat elokuvallista elämystä. Katsomiskokemukset ovat tyylin funktioita paljon enemmän kuin tiedostamme. Ja toisaalta, mikä tyylin funktio sitten kulloinkin onkin, hienoimmillaan "tietyt tyylilliset tapahtumat kristallisoivat tekijän ainutlaatuisen herkkyyden" (Bordwell 2008, 261). Tämä ei rajoitu herkkyyteen elokuvallisten keinovarojen suhteen vaan myös herkkyyteen sille, miten elokuvissa käsiteltävät asiat artikuloituvat tyylin kautta, ehkäpä suorastaan avartaen ymmärrystämme noista asioista.

Vaikka tyyli voi olla hyvinkin yksilöllinen, jopa idiosynkraattinen, se muodostuu tekijöiden tunteman tyylillisen kirjon omaksumisesta ja työstämisestä ilmaisemaan tuota omaperäisyyttä. Taiteellinen ilmaisu luovimmillaankin syntyy suhteessa varhaisempiin taiteellisiin ilmentymiin, joiden keinoja se hyödyntää, kehittelee, radikalisoi tai korvaa. Tyylihistorian tehtävä on kartoittaa, kuinka taiteen tekemiseen on vaikuttanut eri tahoilla tapahtuneiden keinovarojen kehkeytyminen sekä noiden kehityssuuntien välinen vuorovaikutus. Tähän kuuluu myös sen arvioiminen, miten haltuun otettuja keinovaroja on hyödynnetty uusissa konteksteissa.

Metodiikan luomisessa tyylillisten vaikutusten analysoimiseksi on kolme vaihetta: 1) Kartoitetaan tyylin keskeiset funktiot elokuvataiteessa ylipäätään. 2) Luodaan taksonomia keinoista ja käsitteistä, joilla tyylin eri ulottuvuuksia voidaan eritellä. 3) Taksonomian perusteella esitetään tyylitutkimuksen protokolla, joka toimii vahvana perustana tyylillisten vaikutteiden assimilaation tutkimukselle. 4) Tältä pohjalta määritellään perusteet suurtenkin korpusten, vaikkapa koko suomalaisen elokuvan tyylillisen kehityksen, vertailevalla analyysille.

Tässä yhteydessä ei ole mahdollista esittää täysimittaista sovellutusta näin muotoutuvasta metodologiasta. Johdatuksena käytäntöön toimii siksi A Transnational History of Finnish Cinema -projektin myötä syntynyt esitys siitä, 
millaisilla perusteilla suomalaisen elokuvan eri vaiheiden tyylillisiä ulottuvuuksia suhteessa toisaalla tapahtuneeseen kehitykseen on mielekästä tutkia.

\section{Tyylin ja sen analyysin ulottuvuudet}

David Bordwell on esittänyt ytimekkään ja käyttökelpoisen elokuvallisen tyylin määritelmän: se on "elokuvallisten tekniikoiden systemaattista ja merkityksellistä käyttöä" (Bordwell 1997, 4). Hän korostaa tyylin olevan tärkeä tekijä:

[K]oska se, mitä ihmiset kutsuvat sisällöksi, välittyy meille mediumin tekniikoiden "kuvioidun"1 käytön kautta [...] Tyyli on elokuvan konkreettinen tekstuuri, havainnoitava pinta, jonka kohtaamme katsellessamme ja kuunnellessamme, ja tuo pinta on lähtökohtamme, kun liikumme kohti tarinaa, teemaa, tunnetta - kaikkea, millä on meille väliä. (Bordwell 2005, 32.)

John Gibbs ja Douglas Pye kehittelevät tätä ajatusta esittämällä tyylin olevan enemmän kuin joukko materiaa koskevia päätöksiä; se on verkko, tekstuuri, kuvio, tai mekanistisemmin, systeemi $(2005,11)$. Elokuvan tyyliä olisi siis tutkittava systeeminä, joka:

- artikuloi elokuvan antamalla sille tietyn ilmiasun ja ominaislaadun tyyli on tämä artikulaatio.

- synnyttää odotuksia varsinkin suhteessa lajityyppiin ja sen konventioihin.

- ohjaa katsojan huomion keskittymistä ja sitä, mitä ylipäätään havaitaan.

- ohjaa diegeesiksen hahmottamista: aika, tila, kausaliteetti, toiminta.

- säännöstelee kerronnallista informaatiota ja siten kerronnan hahmottamista ja dramaturgiaa.

- ohjaa yksityiskohtien havaitsemista ja merkityksellistymistä.

- antaa elokuvalle tietyn affektiivisen sävyn (hektinen-rauhallinen, iloinen-surullinen, loistelias-pelkistetty).

- voi kiinnittää huomion itseensä siinä määrin, että siitä muodostuu auto-nominen ilmaisun taso.

Historiallisessa poetiikassa on perehdytty siihen, miten erilaiset tuotannolliset olosuhteet ja niissä käytössä ollut tekniikka sekä tietotaito ovat ehdollistaneet, millaisiin tyylillisiin ratkaisuihin on päädytty. Tämän suuntauksen avainteos on Bordwellin, Thomsonin ja Janet Staigerin Classical Hollywood Cinema (1985). Nykyisin elokuvantekijöillä on jopa suhteellisen pienen budjetin tuotannoissa käytössään valtava keinovarasto, joilla toteuttaa tyylillisiä funktioita laadukkaasti. Elokuvallisen tyylin systemaattisella analyysillä on näin ollen kaksi puolta: kartoittaa, mitä erilaisia tyylillisiä mahdollisuuksia on käytetty ja miten ne toteuttavat yllä lueteltuja funktioita. Nyt meillä on käytettävissä uusia keinoja, joilla analyysiä voidaan tehdä systemaattisesti ja vertailukelpoisesti, mikä puolestaan vahvistaa tyylillisten vaikutteiden leviämisen tutkimusta.

Tyylianalyysin metodiikan kehitteleminen on hyvä aloittaa erittelemällä, mitkä sen tekijät ovat tarkasteltavissa enemmän tai vähemmän objektiivisin kriteerein. Kun aloitetaan objektiivisimmista keinoista, saadaan seuraava menettelytapaluettelo:
1 Sanaa patterned on tässä yhteydessä vaikea kääntää. Graafisten ja jopa musiikillisten teosten tai esitysten yhteydessä sanan kuvio johdannaiset tuntuvat luontevalta, mutta elokuvaan sanan käyttö ei ole ainakaan vielä vakiintunut. Mutta syytä olisi, jollei jollakulla ole ehdottaa parempaa ilmaisua. 
Mittaaminen: Tarkasteltaessa elokuvaa puhtaasti materiaalisena ilmentymänä voidaan kutakuinkin yksiselitteisesti mitata pääasiassa otosten kestoa -jotkut leikkaustyypit tosin hieman heikentävät parametrin täsmällistä mitattavuutta. Internettyökalu Cinemetrics tarjoaa erinomaisen välineen mittauksen tekemiseen sekä saadun datan havainnollistamiseen. Järjestelmän tietopankkiin on jo nyt tehty analyysit suuresta joukosta elokuvia, sekä otospituuksien että monien muiden mitattavissa tai luokiteltavissa olevien tyylillisten piirteiden vertailevaa tutkimusta varten. Otosten kestojen ja niiden vaihteluiden tarkastelu tarjoaa vankan objektiivisen pohjan tyylin erään keskeisimmän parametrin analyysille.

Luokittelu ja laskeminen: Tietyt tyylilliset parametrit ovat luokiteltavissa, joskaan ei täysin selvärajaisesti. Tärkein ulottuvuus tässä suhteessa ovat kuvakoot. Tätä varten on olemassa mielekäs, lähinnä käytännön tarpeista kehittynyt kahdeksanportainen asteikko ${ }^{2}$, jonka pohjalta voidaan laatia laskelma kuvakokojen määristä ja jakaumista (shot scale distribution, SSD). Samaan tapaan voidaan laskea minkä tahansa suhteellisen vakiintuneen elokuvallisen keinon, kuten erilaisten kameraliikkeiden, kuva-vastakuva-jaksojen tai näkökulmaotosten määrät ja kuva-asetelmien toistumiset. Ainakin periaatteessa voitaisiin luokitella ja laskea vaikkapa tiettyjen maneerien tai muiden näyttelijäntyöhön liittyvien ilmaisullisten keinojen esiintymistä. ${ }^{3}$

Kuvailu: Kuvailun merkitys korostuu ennen kaikkea näyttämöllepanon eri ulottuvuuksien tarkastelussa, mutta myös monien luokiteltavissa olevien tyylillisten keinojen arvioiminen edellyttää niiden kuvailua. Esimerkiksi kameraliikkeiden analyysissä on usein tarpeen määritellä ainakin lähtö- ja lopputilanne, mitä ja millaisessa rajauksessa näissä tilanteissa ja ehkä myös niiden välillä nähdään. Näin kameraliikkeen kuvailu kytkeytyy olennaisesti näyttämöllepanon kuvailuun. Myös liikkeen nopeus on tärkeää tietoa, joka sekin käytännössä täytyy ilmaista varsin yksinkertaisilla kuvailevilla termeillä, kuten nopea tai hidas. Kaikki nämä tekijät ohjaavat ratkaisevassa määrin katsojan huomion keskittymistä ja sen myötä tarinan seuraamista, tematiikan hahmottumista sekä affektiivista vaikutelmaa.

Sisäinen kontekstualisointi: Miten mitattavissa ja luokiteltavissa olevat elokuvailmaisun ulottuvuudet toimivat suhteessa diegeettiseen kontekstiin? Esimerkiksi otospituuksien vaihtelut tai kamerapositiot liittyvät elimellisesti dramaattisen tilanteen ilmentämiseen, ja tyylillisen analyysin on kyettävä erittelemään nämä yhteydet. Kontekstualisointi kulkeekin usein käsi kädessä kuvailun kanssa: on kuvailtava sekä käytettyä keinoa (esimerkiksi kameraajoa) että sen synnyttämää vaikutelmaa.

Yeistäminen: Mitattavissa ja luokiteltavissa olevien tyylikeinojen analyysi voi kohtuullisella vaivalla kattaa koko elokuvan. Voidaan myös tehdä kuvaileva lista vaikkapa kamera-ajoista ja etsiä niistä kontekstualisoituja yhtäläisyyksiä esimerkiksi tematiikan tasolla. Jotkin yleistykset tyylistä kuitenkin lähes välttämättä perustuvat tuntumalle siitä, että erityisen tarkastelun kohteeksi valikoituneet kohtaukset tai jaksot ovat edustavia. Onneksi on verraten helppo tarkistaa, löytyykö elokuvista selvästi poikkeavia jaksoja. Viscontin elokuvan Kuolema Venetsiassa (Morte a Venezia, Italia 1971) alkupuolen salonkikohtauksessa hienovarainen panoroinnin ja zoomausten yhdistelmä paitsi hahmottaa tilaa ja näyttää siellä oleilevia henkilöitä myös ilmentää henkilösubjektiviteettia häilymällä objektiivisen ja subjektiivisen näkökulman välillä. Jakso toimii tässä
2 Kahdeksanportainen asteikko määrittelee tavallisesti kuvakoot seuraavasti:

Yleiskuva, YK (extreme long shot, ELS): suurin kuvakoko, hyvin laaja näkymä, ympäristö on pääosassa. Henkilöt erottuvat pieninä. Laaja kokokuva, LKK (long shot, LS): esittelee edelleen ympäristöä laajasti, henkilö näkyy kuitenkin suurempana kuin yleiskuvassa. Kokokuva, KK (full shot, FS): henkilö näkyy kuvassa kokonaan. Myös ympäristöä on näkyvissä. Laaja puolikuva, LPK (long medium shot, LMS): henkilö rajataan suunnilleen reiden tienoilta. Puolikuva, $\mathrm{PK}$ (medium shot, MS): henkilö rajataan navan tienoilta. IImeet alkavat erottua. Puolikuva, PLK (medium close-up, MCU): henkilö rajataan rinnan korkeudelta. Lähikuva, LK (close-up, $\mathrm{CU}$ ): henkilö rajataan solisluiden kohdalta. Erikoislähikuva, ELK (extreme close-up, ECU; engl. big close-up, BCU): hyvin tiivis rajaus, esim. kasvot otsasta leukaan, tai vielä pienempi yksityiskohta, kuten silmä. (Max Juntusen Elävän kuvan sanaston mukaan.)

Rajat kuvakokojen välillä eivät tietenkään ole yksiselitteisiä. Kahdeksanportainen asteikko ei myöskään ole täysin universaali, ja käytössä on sekä enemmän että vähemmän kuvakokoja sisältäviä asteikkoja.

3 Jaakko Seppälä esittelee näitä mahdollisuuksia tässä Lähikuvan numerossa ilmestyvässä katsauksessaan, joka käsittelee Cinemetricsin olemassa olevia ja potentiaalisia käyttömahdollisuuksia. 
tyylillisesti hyvin yhtenäisessä teoksessa johdatuksena sekä näiden kameratekniikoiden että katseiden funktioihin ja merkityksiin kautta koko elokuvan.
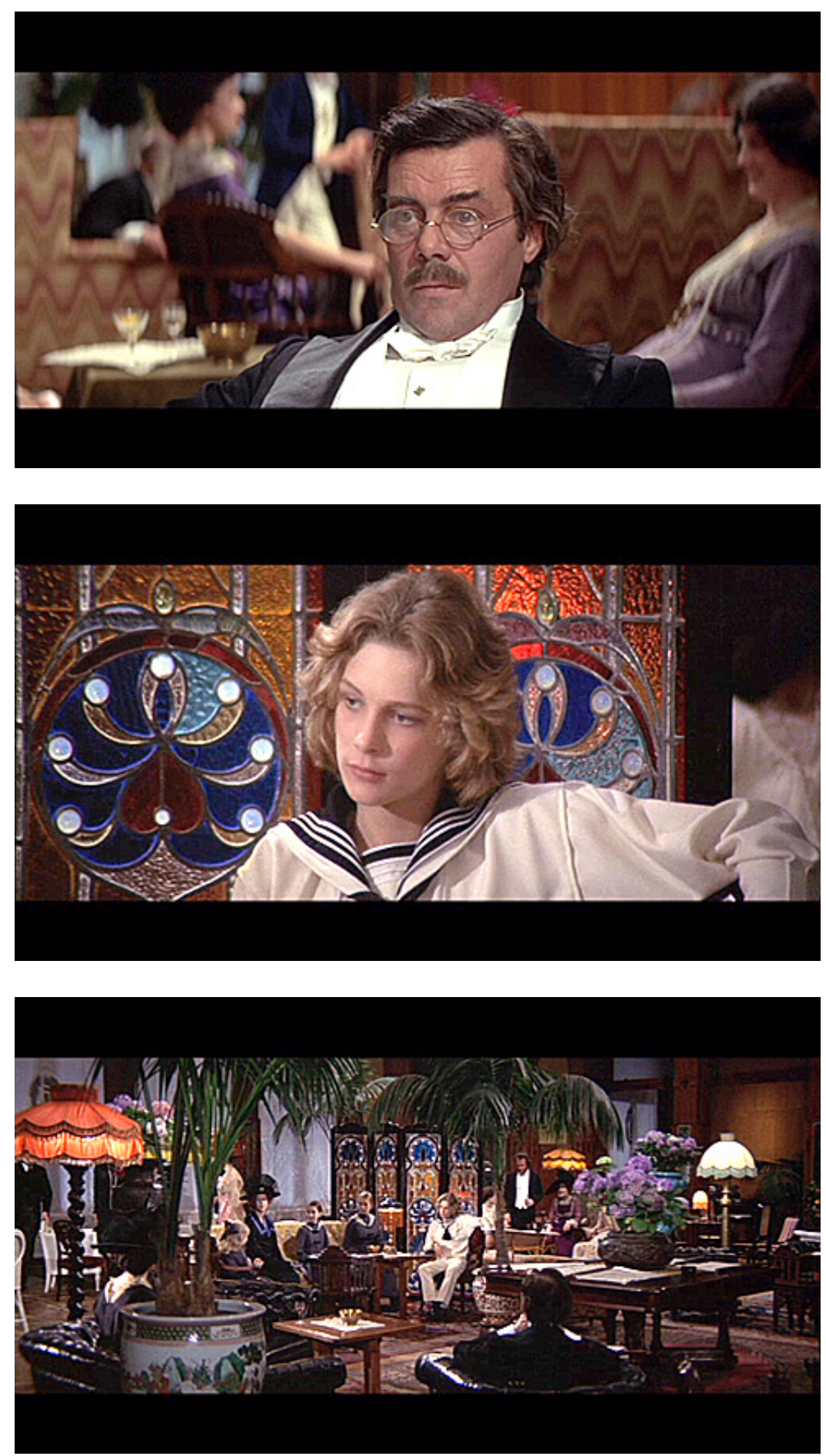

Visconti, Kuolema Venetsiassa (1971). Aschenbachin huomio kiinnittyy johonkin. Seuraavassa kuvassa näkyy hänen katseensa kohde, kaunis nuori poika. Mutta kun kamera zoomaa hänestä pois, Aschenback näkyy kuvassa takaapäin. On kuin näkökulmaotos olisi zoomauksen myötä muuttunut objektiivisemmaksi näyttäen lopulta sekä katselevan henkilön että katseen kohteen. Kuvat: kuvakaappauksia DVD:Itä. 
Listan järjestys ei tietenkään implikoi sitä, että ensiksi mainitut metodit olisivat tärkeämpiä tai relevantimpia tyylitutkimuksen kannalta kuin loppupuolella mainitut. Tyylin kannalta ulottuvuudet, jotka ovat tavoitettavissa vain suhteellisen impressionistisen kuvailun kautta, ovat aivan yhtä tärkeitä kuin mitattavissa ja luokiteltavissa olevat. Ero on lähinnä siinä, että ominaisuuksien, kuten otospituuksien ja kuvakokojen, voidaan mieltää luovan rakenteen, jonka puitteissa kuvailua vaativat tyylilliset ominaisuudet luovat vaikutelman diegeettisestä maailmasta sen kaikessa fenomenaalista maailmaa lähentelevässä moninaisuudessa. Niinpä on syytä tarkastella tarkemmin, ensin miten tietyt tyylin ulottuvuudet ovat analysoitavissa mittaamisen, luokittelun ja laskemisen kautta, ja sitten mitä on tarkasteltava kontekstualisoinnin, kuvaamisen ja tulkinnan kautta. Raja näiden välillä ei tietenkään ole selvä.

\section{Tyylin tutkimusta lukujen pohjalta}

Kuten todettiin, Cinemetricsin avulla voidaan tehdä vertailevaa tutkimusta esimerkiksi keskimääräisen otospituuden (average shot length, ASL) vaihteluista läpi suuren osan elokuvahistoriaa. Barry Salt on tehnyt jo aiemmin pioneerityötä tässä suhteessa osoittaen muun muassa, että keskimääräinen ASL amerikkalaisessa elokuvassa vuosina 1918-23 oli huomattavasti lyhempi kuin eurooppalaisessa (6,5 sekuntia vs. 8,5 sekuntia) ja että kun eurooppalaiset saivat amerikkalaiset kiinni tässä suhteessa, nämä kehittelivät entistäkin reippaampia leikkaustyylejä yltäen seuraavan viiden vuoden aikana 5,8 sekuntiin siinä, missä eurooppalaisten saavutus tässä vaiheessa oli 6,5 sekunnin keskimääräinen ASL (Salt 2009, 192). Cinemetricsin tietopankki tarjoaa nykyään alati vahvemman ja laveamman pohjan tällaisten elokuvahistoriallisten vertailujen tekemiseen. Cinemetrics myös helpottaa sen tutkimista, millaista varianssia lukuihin sisältyy. Ongelmaksi muodostuu lähinnä yksittäisen elokuvan mahdolliset erilaiset versiot ja käytettävissä olevien kopioiden kunto. Mykkäelokuvien kohdalla lisävaikeutena on oikeasta - tai pikemminkin perusteltavissa olevasta - projektionopeudesta päättäminen.

Cinemetricsin tietopankki tarjoaa mahdollisuuden myös sen selvittämiseen, miten otospituuksien vaihtelut läpi yksittäisen elokuvan korreloivat vastaavaan vaihteluun eri elokuvakorpuksissa. Jaakko Seppälä on tehnyt tarkkoja vertailuja siitä, kuinka hidas Aki Kaurismäen eri elokuvien rytmi on suhteessa ajan muihin elokuviin ja kuinka paljon hitaampia varsinaisten hitaan elokuvan mestarien, kuten Bela Tarrin, työt ovat (Seppälä 2015, 26). Otospituuksien ja sen myötä leikkaustiheyden relevanssin kartoittaminen tuo mukaan kuvailun ja tulkitsemisen, sillä näiden vaihtelut ajan funktioina eivät ole riittävän informatiivista: haluamme tietää, miten vaihtelut korreloivat elokuvan sisältöön ja mitä funktioita sillä siihen nähden on. Viime kädessähän keskeisin tyyliä koskeva kysymys on, miten se ohjaa katsojan huomiota ja eläytymistä tiettyjen vaikutelmien synnyttämiseksi.

Samanlaista analyysiä voidaan tehdä suhteessa kuvakokoihin, ja parhaimmillaan voidaan esittää hyvinkin valaisevia diagrammeja kuvakokojakaumista jonkin ohjaajan tuotannosta sen eri vaiheissa. ${ }^{4}$ Tilastojen tarkkuutta ja vertailtavuutta kuitenkin heikentävät luokittelun lievä sumeus sekä tietty anakronistisuus: kahdeksanportainen luokittelu on luotu kuvaamaan ennen kaikkea klassisen kerronnan vakiintumisen myötä standardisoituneita rajauksia ja niiden mukaista kerrontaa. Lisäksi asteikko on määritelty pää-
4 Erinomainen esimerkki SSD:n vaihteluiden tutkimisestä yksittäisen ohjaajan tuotannossa on András Bálint Kovácsin artikkeli "Shot Scale Distribution: An Authorial Fingerprint or Cognitive Pattern". 
asiassa ihmisruumiin rajausten mukaan, joten kun kuvassa ei ole henkilöä, sen soveltaminen on hieman heikommalla pohjalla.

Paljon mielenkiintoisempia ongelmia syntyy, kun kuva-alassa on eri tasoja: jokin elementti voi olla hyvinkin tiukassa rajauksessa etualalla samalla, kun taaempana yleiskuvassa tapahtuu jotakin, joka myös vaatii huomiotamme. Laskennallinen analyysi tällaisista tapauksista voi olla tavattoman antoisaa. András Bálint Kovács on Antonionin koko tuotannon kattavassa analyysissään osoittanut, että puolilähikuvien määrä hänen elokuvissaan on käänteisesti verrannollinen otostyyppiin, josta hän käyttää nimitystä foreground shot (etuala-otos). Tämä on loogista, koska etualalla oleva elementti näkyy tässä otostyypissä usein puolilähikuvaa vastaavassa koossa. (Kovács 2014, 51, 61.) Otostyyppiä ei kuitenkaan voi redusoida tähän kategoriaan, koska taustalla nähtävillä asioilla on oma painokkuutensa. Kun tällaisia otoksia voi olla jopa 30 \% elokuvan kaikista otoksista, kyseessä on merkittävä tyylillinen elementti. Viimeistään tässä vaiheessa on myönnettävä, että puhdas klassinen kuvakokojen luokittelu ei ole aina mahdollista ja että jotkin tapaukset pakoilevat lineaarista kategorisointia. Täysin kattavaa ja systemaattista SSD-kaaviota ei tällöin voida tehdä. Mutta kuten Kovács osoittaa, tältä pohjalta voidaan silti vertailla jonkun ohjaajan tuotannon eri vaiheita jonkun mielekkäällä tavalla rinnastettavissa olevan ohjaajan tuotantoon - tässä tapauksessa toisen modernismin mestarin, Bergmanin, vastaavan ajanjakson elokuviin. ${ }^{5}$

Kameratyöhön liittyy useita ulottuvuuksia, kuten polttoväli ja tarkennus, jotka ovat teknisessä mielessä mitattavissa ja määriteltävissä. Mutta käytännön analyysissä ei useinkaan vastaa tarkoitusta yrittää päätellä, millä polttovälillä jokin otos tarkkaan ottaen on otettu, sillä yleensä riittää puhuminen laajakulmasta, normaaliobjektiivista ja kauko-objektiivista, ehkä joillakin adjektiiveilla tarkennettuna. Epätarkkuus vastaa jossakin määrin sitä, että havaintomme kalibroituu monessa suhteessa ympäristön mukaan, emmekä aina kykene tekemään erityisen hienosyisiä erotteluja visuaalisesta kentästämme ilman huomattavaa tietoista harjoitusta. Vaikka kuvan hahmottaminen tapahtuu

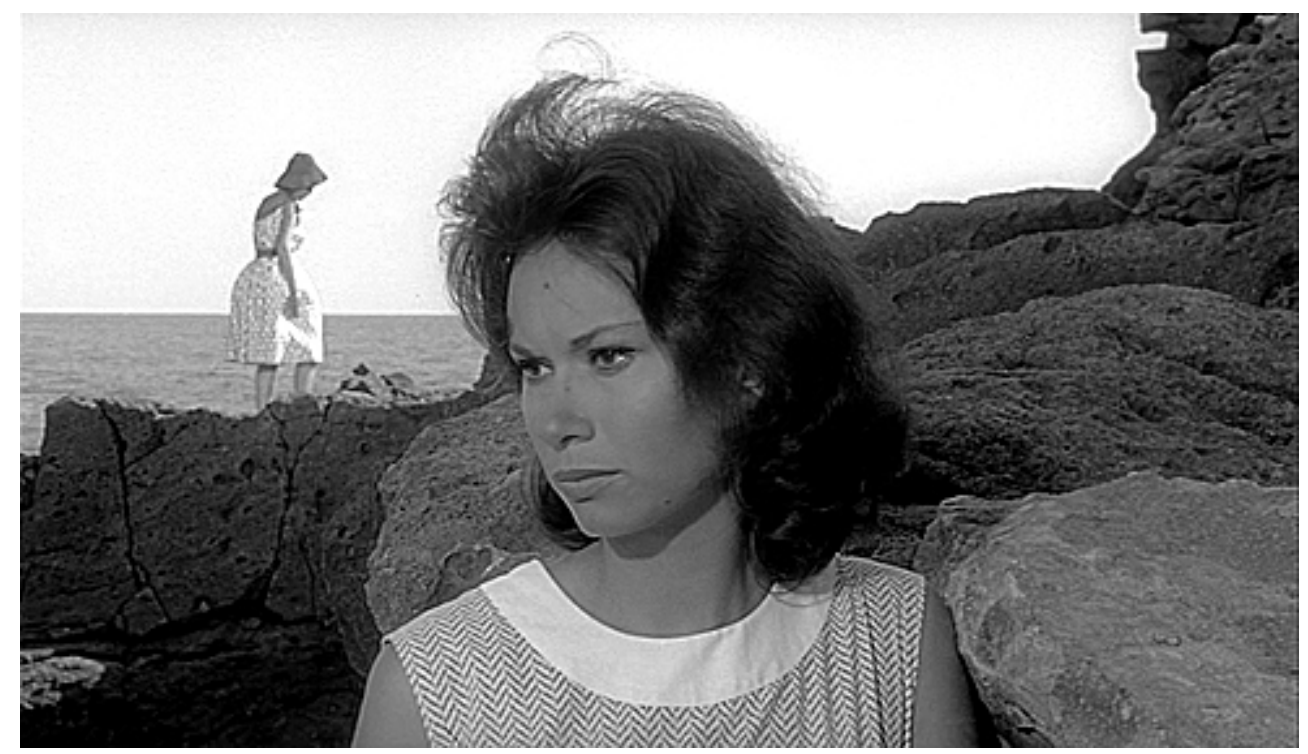

Antonioni, Seikkailu (1960). Kovácksin etualakuvaksi määrittelemässä otoksessa Anna näkyy lähikuvassa, mutta myös taustalla on toimintaa. Kuva: kuvakaappaus DVD:Itä.
5 Kovácsin analyysin tarkkuuden kannalta on tärkeää, että hän ei analysoi vain eri kuvakokoihin kuuluvien otosten määriä vaan myös niiden kestoa sekunnilleen. Hän korostaa tämän tarjoavan vahvemman pohjan paitsi vertailuille myös yksittäisen elokuvan kokonaisanalyysille (Kovács 2014, 54). 
pitkälti samojen skeemojen varassa kuin ympäristön hahmottaminen, keinot, kuten tarkkuusalueen vaihtelut, asettavat havaintoapparaatillemme lisähaasteen. Koska visuaalinen havainto rakentuu vasta aivoissamme eikä verkkokalvolla, eletty ympäristö näyttäytyy meille useimmiten huomiomme kohdistumisen myötä tasaisen tarkkana silmämme optiikasta riippumatta. Vaatii pientä lisäponnistusta "nähdä" kuinka rajallinen näkökenttämme todella on. Valokuvallisessa representaatiossa asiat näyttäytyvät usein varsin selvästi joko tarkkoina tai sitten ei. ${ }^{6}$ Esteettiseen efektiin tähtäävissä kaukoobjektiivilla tallennetuissa otoksissa henkilöiden tausta (joskus myös jokin etualalla oleva elementti) näkyy kauniin usvaisena. Tällainen efekti on mahdollista vain projektiossa, sillä normaalihavainnossa visuaalinen kenttämme tarkentuu havaintomme kohdistumisen myötä.

Ammattilainen saattaa kyetä esittämään teknisen kuvauksen siitä, miten ja miksi johonkin ratkaisuun tarkkuusalueen suhteen on päädytty, alkaen siitä, millaista tekniikkaa - optiikka, kameran aukko, valaistus, filmityyppi, kuvan prosessointi - todennäköisesti on ollut saatavilla tietyssä tuotannollisessa ja kuvauksellisessa kontekstissa. Muut kuin ammattilaiset kuvaajat voisivat päästä näille jäljille esimerkiksi kuvauksen dokumentoinnin kautta ja tuoda esille todella mielenkiintoisia seikkoja. Vertailevan tyylitutkimuksen kannalta tällaisilla tiedoilla on relevanssia lähinnä perehdyttäessä siihen, millaista teknologiaa ja tietotaitoa jossakin historiallisessa kontekstissa on ollut käytettävissä ja miten tämä on mahdollistanut tyylillisten vaikutteiden adaptaation ja erilaisten esteettisten efektien luomisen osittain vaikutteiden, osittain oman visuaalisen herkkyyden pohjalta. Näiden kuvailua helpottaa tavallaan juuri se, että kamera artikuloi visuaalista kenttää toisin kuin luonnollinen havaintomme, ja voimme tehdä kielellisiä erotteluja tarkkuusalueen suhteen kameran optiikkaa koskevan käsitteistön perusteella.

Kameraliikkeiden analyysi puolestaan vaatii paljon kuvausta, ja objektiiviset parametrit toimivat lähinnä kehikkoina, joiden puitteissa tulkinta tapahtuu. Ensimmäinen vaihe on kuvata ylipäätään kameran liikettä diegeettisessä maailmassa, toinen sen tarinafunktiota suhteessa tarinan henkilöihin ja mahdollisesti heidän subjektiviteettiinsa ja kolmas liikkeen oletettavissa olevaa kerronnallis-elämyksellistä vaikutusta katsojaan. Samantapaista skematiikkaa täytyy tietysti soveltaa useimpien elokuvallisten keinojen analyysin suhteen. Analyysin pohjalta olisi luotava synteesi, artikuloitava näkemys siitä, miten nämä tekijät osallistuvat tyylin rakentumiseen. Kyse on parhaimmillaankin hyvin artikuloidusta impressiosta, mutta tätä ei voida pitää heikkoutena: jos jokin asia ei olemuksellisesti palaudu mitattavissa oleviin suureisiin, ei ole mielekästä moittia sen tarkastelua systemaattisuuden puutteesta. Ja vaikka ei ole helppoa rinnastaa kameranliikkeitä numeraalisesti tai graafisesti esittävää dataa, voidaan silti vertailla kuvauksia siitä, miten esimerkiksi kamera-ajot toimivat eri elokuvissa tai eri ohjaajien tuotannoissa.

Monet muutkin keinot, kuten standardisoituneet leikkaustavat, ovat luokiteltavissa ja laskettavissa mutta usein eivät niinkään selkeästi kuin kuvarajaukset. Leikkaukset voidaan toki luokitella verraten selvärajaisesti (suora leikkaus, ristikuva, häivytys-nosto, pyyhkäisy jne.). Mutta on valtavan paljon muitakin, usein kuvailua vaativia, parametreja huomioitavana. Leikkauksen suhteen on otettava huomioon myös rajauksen muutokset, jatkuvuustekijät, erilaiset visuaaliset paralleelit ja kontrastit, otosten kesto ja leikkausrytmi sekä tietysti suhde sisältöön niin tarinan kuin teemojenkin tasoilla. Aidosti mielenkiintoisia tuloksia saavutetaan vasta, kun tarkastellaan, onko näitä käytetty vallitsevien normien mukaisesti vai menemällä niitä vastaan sekä
6 Periaatteessa jollakin polttovälillä vain yksi tietyllä etäisyydellä oleva taso on tarkasti fokuksessa, mutta käytännössä tarkaksi mielletään laajempi syvyys, jonka laajuus riippuu käytetystä optiikasta. Tarkkuusalue jakautuu niin, että noin $1 / 3$ siitä on matemaattisen tarkan alueen edessä, $2 / 3$ sen takana. 
selvittämällä, millaisen vaikutelman tämän voisi olettaa synnyttävän. Kun Martin Scorsese elokuvissa, kuten Taksikuski (Taxi Driver, USA 1976) tai Illasta aamuun (After Hours, USA 1985), alkoi käyttää ristikuvaa synnyttääkseen vaikutelman ajallisesta loikasta ikään kuin yhden otoksen sisällä (ristikuvalla toteutettu jump cut), Hollywood-kerronnassa oli meneillään mikrotason tyylillinen muutos: aikaisempaa entistä vähemmän ristikuva merkitsi selvää siirtymistä selvästi eri aikaan tai paikkaan. Tällaisen leikkauksen frekvenssi voi toimia yhtenä tyylimuutoksen mittarina. Parasta olisi kuitenkin ottaa tarkastelun piiriin mahdollisimman monta samanaikaista muutosta elokuvallisten ilmaisukeinojen käytössä.

Sergei Eisensteinin hienosyisten montaasikeinojen luokittelujen ${ }^{7}$ esiintymät yksittäisessä elokuvassa ovat periaatteessa laskettavissa. Käytännössä luokittelu voi kuitenkin olla vaikeaa, minkä lisäksi on jälleen turvauduttava kuvailuun ja tulkitsemiseen. Yksittäisten montaasinlajien ilmentymiä relevantimpaa onkin tarkastella sitä, kuinka montaasi korkeammaksi taiteelliseksi periaatteeksi nostettuna on löytänyt tiensä niinkin erilaisiin teoksiin kuin Why We Fight -dokumenttielokuvien sarjaan (1942-1945) tai kuinka Godardin ja joidenkin muiden eri uusien aaltojen ohjaajien montaasi-tyylilliset vaikutteet saavat omaperäisen ilmiasun vaikkapa Jarvan Työmiehen päiväkirjassa (Suomi 1966). Yhdistävänä tekijänä on ideologiseksi luonnehdittava montaasi sinänsä, pikemminkin kuin se, millaisilla periaatteilla otosten yhdistäminen käytännössä tapahtuu. Tämä palautuu monenlaisiin kontekstuaalisiin kysymyksiin.

Klassisen tyylin puitteissa voimme myös laskea tavanomaisimpien leikkauskuvioiden tai jaksojen, kuten näkökulmaotosten ja kuva-vastakuvaasetelmien määrät ja pituudet. Molempien kohdalla voi esiintyä tyylin kannalta merkittävää varianssia - kameran paikka ja optiikka voivat vaihdella suurestikin sekä näkökulmaotosten että katsovaa henkilöä näyttävien otosten kohdalla; keskustelevat henkilöt saattavat liikkua niin, että kuva-vastakuvajaksojen rajaukset, taustat ja valaistukset vaihtelevat ilmaisevalla tavalla - ja jälleen tarvitaan kuvausta ja ainakin perustason tulkintaa. Esimerkiksi Sirkin Kaikki minkä taivas sallii -elokuvassa (All that Heaven Allows, USA 1955) mies-ja naispäähenkilön välillä käydään tunteikas välienselvittely huoneessa, jossa valo tulee pääasiassa suuren ikkunaseinän suunnalta. Kun henkilöt liikkuvat suhteessa siihen ja toisiinsa, valojen ja varjojen balanssi heidän kasvoillaan vaihtelee jatkuvasti keskustelun edetessä antaen sille hienovaraisesti vaihtelevan affektiivisen sävyn. Hienosti toteutettu jakso toimii ennen kaikkea esimerkkinä siitä, millaisia potentiaaleja niinkin vakioiseen keinoon kuin kuva-vastakuva-jaksoon sisältyy; pikemminkin kuin, että se toimisi suoraan kopioitavissa olevana mallina.

Ajatus tyylillisten vaikutusten leviämisestä adaptaationa pikemminkin kuin jäljittelynä pätee vieläkin vahvemmin yhteen kaikkien keskeisimmistä tyylillisistä kysymyksistä, nimittäin kuvajakoon. Cinemetrics taipuu varmasti myös siihen, että voidaan paitsi laskea otosten ja käytettyjen kuvakokojen määrä myös kameran sijoittuminen diegeettisessä tilassa kussakin otoksessa. Lisäksi on kyettävä esittämään, kuinka kaikki tämä synnyttää vaikutelman jatkumolla staattinen-dynaaminen, miten liikkeet, toiminta ja tarina virtaavat leikkauksen myötä, joko puhtaasti näyttelijätyön kautta staattisessa otoksessa - kuten useimmiten Roy Anderssonin elokuvissa - tai sitten hyvinkin kompleksisen montaasin kautta - esimerkiksi Thelma Schoonmakerin leikkaamissa Scorsese-elokuvissa. Vertailevassa tyylitutkimuksessa mahdollisuuksia voidaan kartoittaa käyttämällä merkkipaaluina tällaisia tunnettuja vertailukohtia, mutta vähemmän tunnetun omintakeisen elokuvatekijän leikkaustyylin
7 Eisenstein määritteli viisi montaasin kategoriaa: Metrinen montaasi perustuu palasten pituuteen irrallaan niiden sisällöstä. Otoksia lyhentämällä esim. saadaan aikaan kiihkeämpi tempo. Rytmisessä montaasissa otoksen tempon määrää osaltaan sisältö, joka voi olla yhdenmukainen varsinaisen keston kanssa tai sitten sen kanssa kontrapunktissa. Tonaalisessa montaasissa tärkeää on teoksen emotionaalinen ääni, sen dominantti, jonka määrittävät otoksen hallitsevat teksturaalisten piirteiden, kuten valoisuus-tummuus, terävyys-sameus, emotionaalinen sisältö. Yläsävelmontaasi on kolmen edellisen synteesi. Se on oikeastaan tapa tarkastella montaasia projisointitilanteessa, jossa se ilmenee emotionaalisena värittyneisyytenä ja välittömänä aistittavuutena. Intellektuaalinen montaasi taas on tapa esittää ideoita montaasin kautta luotujen metaforien kautta. 
kuvaaminen voi silti vaatia paitsi suurta herkkyyttä elokuvalliselle ilmaisulle myös huomattavaa verbalisointitaitoa.

Kun kaikkia leikkaukseen liittyviä mahdollisuuksia aletaan tarkata, mahdollista tutkittavaa on niin paljon, että usein täytyy tyytyä erittelemään joitakin edustavina pidettyjä kohtauksia tai tiettyä leikkauksen ulottuvuutta. Ylipäätään ollaan niin moninaisten tyylillisten kysymysten edessä, että on edelleen kehitettävä uusia käsitteellisiä työkaluja tutkimuksen tueksi.

\section{Tyylitutkimus lukujen tuolla puolen}

Tyyliä koskevat tiedostetut ja intuitiiviset odotuksemme ja elokuvan tarjoamaa elämystä koskevat odotuksemme kietoutuvat erottamattomasti yhteen. Tyylin analyysi onkin Gibbsin ja Pyen sanoin "sen tulkitsemista, mitä se saa aikaan" (Gibbs \& Pye 2005, 11). Tähän suuntaan voidaan edetä hedelmällisesti soveltamalla venäläisiltä formalisteilta juontuvaa motivaation käsitettä, jonka Bordwell ja Thompson ovat lanseeranneet elokuvatutkimukseen. He käyttävät sitä eritelläkseen ulottuvuuksia, joiden avulla katsoja voi selittää itselleen, miksi asiat ovat elokuvassa, niin kuin ovat. Hän voi olettaa vaikkapa elokuvan ympäristöjen tai henkilöiden toiminnan vastaavan sitä, miten asiat ovat todellisuudessa tai mitä hän pitää uskottavana inhimillisenä käyttäytymisenä (realistinen motivaatio, RM). Katsoja todennäköisesti myös ymmärtää, että tarve luoda enemmän tai vähemmän koherentti ja ytimekäs tarina sekä kuvitteellinen maailma (diegeesis) ovat johdattaneet tietynlaisiin juonenkuljetuksellisiin tai eritasoisiin rakenteellisiin ratkaisuihin aina kuvan sommittelusta tarinan dispositioon (kompositionaalinen motivaatio, KM). Hänelle lienee selvää myös, milloin kyse on yleisistä kerronnallisista tai erityisesti elokuvallisista konventioista kumpuavista ilmaisullisista keinoista (transtekstuaalinen motivaatio TrM). (Bordwell 1985, 36; Thompson 1988, 16-20.)

Neljännen kategorian (taiteellinen motivaatio, TM) katsoja voi Bordwellin ja Thompsonin tapaan mieltää kattavan kaiken sen, mikä on elokuvassa vain itsensä takia. Taiteellisen motivaation käsite lienee hyödyllisimmillään, jos katsoja mieltää sen tarkoittavan nimenomaan kaikkea uutta luovaa ilmaisua elokuvassa. Tällöin se kontrastoituu erinomaisesti transtekstuaalisen motivaation kanssa: uusien keinojen etsintä kontrastoituu vakioisiin ilmaisukeinoihin turvautumisen kanssa. Vahvimmin tämä kontrasti tulee esille lajityyppielokuvien ja varsinkin modernistiselle elokuvalle tyypillisen ainutkertaisuuden vaatimuksen välillä. Taiteellinen motivaatio on aina läsnä siinä merkityksessä, että kaikilla elokuvassa käytetyillä keinoilla on tavalla tai toisella esteettinen funktio. Se on ilmeisimmillään, kun muut motivaation lajit eivät ole erityisen vahvalla tavalla läsnä (Thompson 1998, 16-19). Kun taiteellinen motivaatio hallitsee, "ilmaisuvälineen materiaalit ja muodot ovat päähuomion kohde" (Bordwell 1985, 53). Tämä saattaa johtaa aivan omanlaiseensa kerrontaan, edustavathan irtiotot ulkoisesta todenkaltaisuudesta, klassisista rakenteista tai vakioisista ilmaisun muodoista ilmaisullisten keinovarojen laajentamista.

Motivaatiot eivät muodosta klassista luokittelujärjestelmää, jossa kaikilla sen alaan kuuluvilla olisi vain yksi tietty paikka. Päinvastoin, motivaatioiden rajat ovat sumeita, ja ne toimivat monenlaisissa yhdistelmissä. Elokuvan visuaalista toteutusta ohjaavat lähes väistämättä myös aihepiirin liittyvät konventiot ja käytännöt (TrM) samoin kuin dramaturgiset päämäärät (KM). Näistä molemmat voivat johtaa edelleen jonkin asteiseen tyylittelyyn (TM). Kaikki nämä ovat vaihtelevassa määrin jännitteisessä suhteessa käsityksiin 
historiallisesta todellisuudesta (RM). Katsojia saattaa kiehtoa ajatus siitä, että esitetyt tapahtumat vastaavat historiallista tai sosiaalista todellisuutta tai että ne ovat ainakin totuudellisia - samalla, kun halutaan seurata hyvin kerrottua ja sen myötä todennäköisesti suhteellisen konventionaalista draamaa. Tyylillisen analyysin kannalta mielenkiintoisinta onkin tarkastella niiden välisiä jatkumoja erityisesti suhteessa realistiseen ja taiteelliseen motivaatioon:

- realistis-kompositionaalinen: missä määrin realismista tingitään lähinnä tarinan ytimekkään kertomisen hyväksi

- realistis-transtekstuaalinen: missä määrin esittämisen konventiot ohittavat todenkaltaisuuden

- realistis-taiteellinen: todenkaltaisuus vs. tyylittely

- transtekstuaalis-taiteellinen: kaavoihin pitäytyminen vs. innovaatio

- kompositionaalis-taiteellinen: tyyli klassisen kerronnan palveluksessa

vs. rakenteen palveluksessa

- assosiatiivisuus: missä määrin tyyli kiinnittää huomiota itseensä ker-

ronnan kustannuksella ${ }^{8}$

Erityisesti näyttämöllepano on suuri haaste systemaattiselle tyylitutkimukselle ja tarjoaa erinomaisen mahdollisuuden käsitteistön soveltuvuuden testaamiseksi. Kompositionaalinen motivaatio eli eri elementtien sijoittelu suhteessa toisiinsa, kuva-alaan ja mahdollisesti vielä kuva-alan ulkoiseen diegeettiseen tilaan on juuri sitä, miten diegeettinen tila artikuloituu. Sikäli kun katsoja panee merkille tästä seuraavan asetelmallisuuden, hän todennäköisesti kokee sen esteettisesti nautinnolliseksi eikä turhaan huolestu realistisen motivaation ohenemisesta. Sama pätee itsetietoiseen tyylittelyyn taiteellisen motivaation saadessa yliotteen.

Nämä kysymykset kytkeytyvät elimellisesti kuvajakoon ja tarkkuusalueeseen. Jo varsin varhaisessa elokuvahistorian vaiheessa oli teknisesti mahdollista luoda hyvinkin syvätarkka kuva, mutta välillä esimerkiksi äänielokuvateknologia rajoitti sen käyttöä. Esteettisesti sen tarjoamia mahdollisuuksia näyttämöllepanossa alettiin toden teolla hyödyntää vasta 1940-luvulta alkaen, paljolti Gregg Tolandin ansiosta. William Wyler ja Orson Welles olivat paljosta kiitollisuudenvelassa hänelle, sillä hänen kameratyönsä mahdollisti dramaturgisesti ennennäkemättömän jännitteisen henkilöiden ja tapahtumien sijoittelun kuva-alassa. Kevyemmät kamerat ja kehittyneemmät pyörillä varustetut kamera-alustat (dollyt, erityisesti ns. crab dolly) helpottivat myös kameran liikkeiden käyttöä dramaturgian painottajana (Beach 2015, 89). Kehitys huipentui steadicam-systeemissä, jossa vakautettu kamera on sidottu kuvaajan ruumiiseen mahdollistaen uudenlaisen sulavuuden ja intensiteetin henkilöiden ja tapahtumien seuraamisessa. Elokuvantekijöille avautui uusia tyylillisiä mahdollisuuksia, etenkin ulottuvuuksilla transtekstuaalis-taiteellinen ja kompositionaalis-taiteellinen. Näiden keinojen leviäminen kytkeytyy teknologian ja tietotaidon liikkuvuuteen sekä edelleen siihen, kuinka paljon esimerkiksi jossakin kansallisessa kontekstissa on uskallusta sijoittaa niiden mahdollistamien tyylillisten keinojen haltuunottoon. Investointeihin on aina kannustanut aiheellinen pelko siitä, että kotimainen tuotanto alkaa näyttää kotikutoiselta.

Varsinaisen näyttämöllepanon puolella lavastus ja puvustus kytkeytyvät usein vallitsevaan käsitykseen muodista ja designista sekä stereotyyppisiin käsityksiin niiden sosiaalisista kytkennöistä. Näin olleen keskeinen tekijä on usein historiallinen ja sosiaalinen konteksti sellaisena, kuin se on elokuvan
8 Loogisesti olisi otettava huomioon vielä yksi pari: kompositionaalis-transtekstuaalinen. Mutta koska lajityyppielokuvat pääsääntöisesti, jolleivat suorastaan määritelmällisesti, pitäytyvät pitkälti klassisessa kerronnassa, tällä käsiteparilla ei todennäköisesti ole paljoa analyyttistä voimaa. 
tekohetkellä mielletty. Kovin paljoa ei ole mielekkäästi kvantifioitavissa, mutta mielenkiintoisia vertailukohtia voi löytyä esimerkiksi siitä, kuinka jokin aikakausi on eri elokuvahistorian vaiheissa lavastettu. Kysymyksenasettelusta riippuen analysoijan saattaa olla tarpeen perehtyä lavastushistorialliseen ulottuvuuteen - miten vaikkapa Jane Austenin romaaneja on visualisoitu eri vuosikymmenillä. Tyylin analysoijan olisi tällöin omattava varsin hyvät tiedot muodin ja designin historiasta voidakseen arvioida, kuinka onnistuneesti aikakausi on elokuvan omien aikalaisten silmissä onnistuttu uudelleenluomaan ja missä määrin siitä on vain otettu aineksia esimerkiksi erilaisiin tunteisiin vetoavan kontekstin luomiseksi. Tällöin operoidaan periaatteessa realistisen motivaation puitteissa, mutta muut motivaation lajit tunkevat melkeinpä väkisin mukaan antaen kokonaisuudelle omat painotuksensa.

Kun otetaan etäisyyttä historiallisesta tai sosiaalisesta realismista, näyttämöllepanon elementit voivat muodostaa lähes autonomisen tason osana elokuvan visuaalista kokonaisuutta. Eräitä äärimmäisyyksiä tässä suhteessa ovat vaikkapa Robert Wienen Tohtori Caligarin Kabinetin (Das Cabinet des Dr. Caligari, Saksa 1920) ekspressionistinen tyylittely ja Stanley Donenin Hätävalheen (Indiscreet, USA 1958) design-ilottelu. ${ }^{9}$ Hieman tavanomaisemmin esimerkiksi muotitrendejä on paitsi hyödynnetty myös kehitelty ja ironisoitu elokuvantekijöiden tarkoitusperien ja usein myös huumorintajun mukaan. Voisi väittää, että katsojakompetenssiin kuuluu kyky ainakin summittain ymmärtää elokuvan visuaalisen ilmiasun ainakin jossakin määrin poikkeavan todellisuudesta, ovat syynä sitten kompositionaaliset, transtekstuaaliset tai taiteelliset tekijät - tai vain budjetin rajallisuus. Tyylin analysoijan ainakin olisi kyettävä kuvaamaan tuota ilmiasua suhteessa motivaatioiden ulottuvuuksiin ja esittää sen pohjalta tulkintansa, miten näyttämölliset elementit toimivat muiden elokuvallisten keinojen artikuloimana osana kokonaisuutta.

Valaistusta voidaan kuvailla laveahkoin formalistisin käsittein, mutta sen ilmaisullisten ulottuvuuksien täsmällisempi luonnehtiminen on haastavampaa. Joskus tässä auttavat studiovalaistuksen perustekniikoiden tuntemus, ennen kaikkea klassinen kolmipistevalaistus (päävalo, tasoitusvalo, taustavalo), joka studiokaudella edesauttoi valokuvauksellisten näyttelijöiden glorifiointia. Nopeammat filmilaadut ja tehokkaammat linssit mahdollistivat paitsi syvätarkan kuvauksen myös kompleksisen valaistusjärjestelmän kehittämisen - John Alton käytti ilmaisua eight-light system kuvaamaan kypsän studiokauden valaistusteknisiä mahdollisuuksia. Muun kuin alan ammattilaisen voi olla vaikea eritellä käytettyjä keinoja tarkemmin. Useimmiten riittää, kun määritellään hallitseva valon suunta, voimakkuus runsaasta (high-key) niukkaan (low-key) valaistukseen, laatu terävästä diffuusiin ja voimakkaista kontrasteista sävykkääseen asteikkoon. Joskus saattaa olla tarpeen erotella tarkemmin tiettyä valaistusefektiä. Historiallisen poetiikan kannalta on hyvä tuntea, millaisia filmejä sekä linssi- ja valaistusjärjestelmiä on elokuvahistorian eri vaiheissa ollut käytettävissä sekä kuinka nämä ovat vaikuttaneet valaistusvaikutelmiin.

Edelleen voidaan tarkastella sitä, missä määrin valaistus on realistisesti motivoitu. Varsinkin studiokauden elokuvassa tästä otettiin huomattavia vapauksia jo senkin takia, että käytettyjen filmilaatujen nopeus ei riittänyt pelkästään tietyssä tilassa uskottavasti olevan valon varassa kuvaamiseen. Realistinen motivaatio toimi tällöin summittaisena tekosyynä sille, että valo tulee tietyltä suunnalta ja tietyn laatuisena, ja lopullinen tulos saattoi syntyä kompositionaalisista ja mahdollisesti ilmaisullisista tarpeista pikemminkin kuin todenkaltaisuuden tavoittelusta. Charles Laughton suorastaan leikittelee
9 Nämä kaksi esimerkkiä havainnollistavat myös sitä, että tyylittelyyn saattaa kannustaa yhtälailla henkilösubjektiviteetin ilmentäminen (Caligarin ekspressionistiset elementit voi mieltää sairaan mielen ilmentymiksi) kuin jonkin elämänmuodon ironisen liioitteleva esittäminen. 
näillä konventioilla elokuvassaan Räsynukke (The Night of the Hunter, USA 1955): henkilön kasvoilla saattaa olla valoa, vaikka huoneen ainoa valaisin näyttäisi olevan hänen takanaan. Historiallisen poetiikan näkökulmasta analysoijalla pitäisi olla ainakin kohtuullisen hyvä käsitys elokuvan tuotantokontekstissa käytössä olleista tekniikoista ja materiaaleista sekä siellä vallinneista normeista. Studiokaudella eri studioilla vallitsivat toisistaan hieman poikkeavat normit, jotka johtivat kukin omanlaiseensa tyylittelyyn mutta myös uusien, entistä näyttävämpien ratkaisujen etsintään. Voidaan siis nähdä, että aikakauden valaistusestetiikassa vallitsee yhtäältä luova jännite ennen kaikkea realistisen ja kompositionaalisen motivaation, toisaalta tälle alisteisen transtekstuaalisen ja taiteellisen motivaation välillä.

Vielä nykyäänkin kuvaajat, joiden ihanteisiin kuuluu olemassa olevan valon käyttö, saattavat joutua lisäämään hieman valoa, jotta esimerkiksi näyttelijöiden ilmeet tallentuvat toivotulla tavalla ja jotta heidän liikkumisensa ei kohtuuttomasti rajoittuisi. Analysoijan ei normaalisti tarvitse puuttua tähän, onhan tavoitteena luonnollisuuden vaikutelman synnyttäminen, vaikka se hieman fuskaamista vaatisikin. Kaiken kaikkiaan tämä on aivan tavanomaista: jotta katsoja pystyisi tunnistamaan realistisen motivaation, on käytettävä keinoja, jotka eivät kumpua suoraan todellisuudesta. Yksittäisen analyysin kannalta viime kädessä keskeinen kysymys onkin, millaisia vaikutelmia syntyy ja miten ne todenkaltaisimmillaankin palvelevat dramaturgiaa. Tyylillisten vaikutelmien leviämisen kannalta taas on tarkattava, kuinka uusien tekniikoiden ja tietotaidon omaksuminen on mahdollistanut erilaisten efektien enemmän tai vähemmän luovan haltuunoton.

\section{Näyttelijätyön analyysi}

Ehkä vaikein analysoitava tekijä elokuvassa on näyttelijäntyö. Se on itseasiassa niin kompleksista, että vaikka se muodostaa tarinaelokuvan keskiön, sitä varten ei vieläkään ole kehitelty pitkälle meneviä metodeja. Perusongelma lienee se, että hyvän näyttelijäntyön olennainen komponentti on nonverbaali kommunikaatio, jolle me kaikki olemme kyllä herkkiä mutta jota emme ole erityisen harjaantuneita verbalisoimaan. Kulturalistisesti suuntautuneiden tutkijoiden mukaan ilmeet, eleet ja intonaatiot ovat sitä paitsi niin kulttuurisidonnaisia, että emme voi ilman muuta olettaa ymmärtävämme, miten toisista kulttuureista tulevat niitä käyttävät (Russell 1994). Elokuvien huikea kyky ylittää kansallisia ja yhteiskunnallisia rajoja viittaa kyllä päinvastaiseen. Paul Ekman onkin esittänyt, että on pieni joukko universaaleja ilmeiden perustyyppejä, joiden pohja on perustavaa laatua olevissa ruumiillisissa reaktioissa (Ekman 2003, 23-28). Näiden päälle on sitten rakentunut kulttuurisia ja persoonallisia nonverbaalin ilmaisun tapoja, jotka nekin ovat yleensä hahmotettavissa.

Toinen realistiseen motivaatioon kohdistuvia odotuksia näyttelijäntyön suhteen komplisoiva tekijä on se, että aikaisemmissa elokuvahistorian vaiheissa realistiseksi ylistetyt näyttelijänsuoritukset saattavat myöhempien aikojen katsojien silmissä vaikuttaa koomisen ylinäytellyiltä. Meille ranskalaisen Film D'Art yhtiön tuottama L'Assassinat du duc de Guise vuodelta 1908 tuskin näyttäytyy malliesimerkkinä hillitystä näyttelijäntyöstä, mutta aikalaisille se oli juuri sitä - Griffithinkin kerrotaan ottaneen siitä opikseen (Abel 2005, 236). Ei kuitenkaan ole perusteltua olettaa, että tämä olisi koko näyttelijäntyön historiaa strukturoiva ristiriita. Voimme katsoa monia vuosikymmeniä vanhoja 
elokuvia ilman, että niiden näyttelijätyö hymyilyttäisi meitä tarpeettomasti. Irtiotot realistisesta motivaatiosta kumpuavat toisenlaisista tekijöistä.

Lajityyppielokuviin kuuluvat elimellisesti vakiotyypit, mikä ohjaa vahvasti näyttelijätyöhön liittyviä odotuksia - joskin niidenkin puitteissa uutta ilmaiseva tyyli saatetaan ottaa riemastuneena vastaan. Useimpien lajityyppien puitteissa tekijät todennäköisesti suhtautuvat konventioihin ainakin lievällä ironisella etäisyydellä. Rajoja koetellaan ja päädytään ensin barokkiseen, sitten suorastaan itseparodiseen ilmaisuun ja lopulta täyteen parodiaan. Viimeksi mainittu kytkeytyy myös karrikoimisen problematiikkaan. Näitä sävyjä saattaa olla vaikea tavoittaa motivaatioiden lajien kautta. On hyvä muistaa, että naturalismiin tähtäävässäkin elokuvassa henkilöt, samoin kuin ihmiset todellisessa elämässä, ovat luokiteltavissa sosiaalisessa kentässä heihin kohdistuvan tiedon tai muun intressin perusteella. Tämä tapahtuu usein liittämällä heihin ominaisuuksia, joita kyseiseen ryhmään kuuluvilla katsotaan olevan. Käytännössä voi siis olla hyvinkin vaikea määritellä, missä määrin näyttelijäntyön katsotaan vastaavan yhteiskunnassa laajemmin vallalla olevia käsityksiä, jolloin kyseessä olisi realistinen motivaatio, ja missä määrin kyse on lajityyppikonventioista ja niin ollen transtekstuaalisesta motivaatiosta. Aivan oman lukunsa muodostaa itsetietoisen tyylittelevä näyttelemistyyli esimerkiksi Eisensteinin Iivana Julma -elokuvissa (Ivan Groznyi, Neuvostoliitto 1944, 1946).

Näyttelijäntyössä myös näyttelijän äänellä on keskeinen osuus niin henkilön sosiaalisessa asemoimisessa kuin tarvittavan affektiivisen vaikutelman aikaansaamisessa. Jälleen pohjana ovat todellisesta maailmasta kumpuavat, suurelta osin intuitiiviset käsitykset siitä, miltä erityyppiset ihmiset kuulostavat - mutta muiden motivaatioiden lajien muovaamina. Tosin voidaan spekuloida myös sillä, missä määrin tässäkin suhteessa käsitykset todellisuudesta ovat medioituneita, eli miten käsitykset vaikkapa sosiaalisesta habituksesta ovat muokkautuneet esimerkiksi elokuvallisten representaatioiden kautta. Tyylianalyysin kannalta tärkeintä on kyetä erottelemaan, millaisia affekteja ja vaikutelmia sosiaalisesta asemasta näyttelijän äänenlaatu ja hänen idiominsa synnyttävät, miten nämä tekijät osallistuvat draaman muotoutumiseen sekä missä määrin ne juontavat lajityypillisistä stereotypioista tai rikkovat joko sosiaalisia tai elokuvallisia konventioita.

\section{Ääni tyylin osatekijänä}

Ääni ei ole saanut sille kuuluvaa huomiota tyylitutkimuksessa - eikä aina elokuvatutkimuksessa yleensäkään. Alan käsitteellinen raamattu, Michel Chionin Audio-Vision (1990), käsittelee erittäin ansiokkaasti ääntä elokuvan rakenteellisena ja kerronnallisena ulottuvuutena samalla, kun se tarkastelee elokuvan äänen mieltämisen psykologiaa. Lukuun ottamatta joitakin huomioita äänen osallistumisesta elokuvan temporaalisiin rakenteisiin, sekään ei silti ota kantaa tyylillisiin ulottuvaisuuksiin. Chionin huomioilla on kuitenkin paljon implikaatioita tyylin suhteen, sillä kuten hän monin tavoin tuo esille, elokuvan ääni vaikuttaa jo pitkälti tiedostamattomalla tavalla siihen, miten visuaalinen ja kerronnallinen mielletään: "Riippuen tiheydestä, sisäisestä tekstuurista, laadusta ja etenemisestä ääni voi enemmän tai vähemmän animoida ja rytmittää kuvaa" (Chion 1990, 14). Vaikka nämä parametrit ja niissä tapahtuvat muutokset, kuten tempon, rytmin ja jatkuvuuden vaihtelut, ovat periaatteessa monessa suhteessa objektiivisesti mitattavissa, asiaa sekoittavat 
huomattavasti katselutilanteessa valitut säädöt (vastaava varianssi kuvan suhteen on huomattavasti pienempi ainakin, jos oletetaan, että katsottavana on priimakopio). Niinpä käytännön analyysissä on taasen tyydyttävä suhteelliseen impressionistiseen kielenkäyttöön. Samaan suuntaan vie se seikka, että kykymme erotella auditiivisia ärsykkeitä on huomattavasti heikompi kuin visuaalista vaikutelmaa.

Havaitsemisemme epätarkkuus tulee äänen kohdalla ehkä vieläkin voimakkaammin esiin kuin kuvan, sillä jo pelkän äänen tunnistamisen suhteen meitä on - äänimiesten onneksi - häkellyttävän helppo johtaa harhaan. Kuulemme hämmästyttävässä määrin sitä, mitä näemme tai odotamme kuulevamme. Vaikka äänen tehtävä usein onkin vain tukea realismivaikutelmaa, äänivaikutelma voidaan käytännössä tuottaa täysin keinotekoisesti (sellofaanin rapistelu kuulostaa palavan puun rätinältä, jos kuvassa nähdään nuotio). On myös verbalisoitava äänen luonnetta käsittein, kuten matala/korkea, miellyttävä/ epämiellyttävä sekä tietysti luonnollinen/epäluonnollinen, käyttäen koko kielen tarjoamaa repertuaaria. Jopa arkkineoformalisti Kristin Thompson tyytyy pitkälti kuvailevaan terminologiaan musiikin ja äänen suhteen kuuluisassa analyysissään Iivana Julmasta. Iivanin sairaskohtauksen alkujakson kohdalla hän kuvailee otos otokselta, missä kohtaa millaiseltakin kuulostavan kellon kilahdus kuuluu. Olisi mahdollista, mutta ei erityisen antoisaa, mitata, missä kohtaa kutakin otosta kilahdukset kuuluvat. Sen sijaan verbaali kuvaus, johon kuuluvat myös maininnat siitä, millaiseen otokseen kellon värähtelyn kuullaan jatkuvan, kertoo olennaisen syntyvästä ääniefektistä. (Thompson 1981, 215-216.) Ja koska vain pienen osan kohdeyleisöstä voi olettaa kykenevän mieltämään soinnun sen tonaalisen määritelmän mukaan, on puhuttelevampaa todeta vain: "... kuullaan ensimmäinen sarjasta uhkaavia sointuja." Thompson kyllä turvautuu jonkin verran musiikkiterminologiaan kirjoittaen kuudestoistaosanuotti-kuvioista, niiden sitomisesta ja purkautumisesta (ibid. 209).

Äänen kokeminen on myös hyvin subjektiivista, ja monet ohjaajat ovat käyttäneet ääntä hyvinkin luovilla tavoilla jo kauan ennen dolby-stereojärjestelmien tarjoamia laajennettuja mahdollisuuksia. Esimerkiksi René Clair, Fritz Lang ja Alfred Hitchcock hyödynsivät ääntä nokkelasti jo ensimmäisissä kokeiluissaan tällä alalla. Luokittelu motivaatioiden kannalta hankaloituu, mutta ehkä viisainta on todeta realistisen motivaation kattavan myös sen mahdollisuuden, että elokuva esittää omilla keinoillaan realistisesti subjektiivista todellisuutta. Diegeettinen musiikki voi olla objektiivista ja subjektiivista. Samaa jakoa voi soveltaa niin elokuvan muuhun äänimaailmaan kuin visuaaliseen ilmaisuunkin, yhtenä ääripäänä Pasolinin ajatus vapaasta epäsuorasta kerronnasta, jossa esimerkiksi otos ei ole yksiselitteisesti sen enempää objektiivinen kuin subjektiivinenkaan vaan liikkuu näiden välillä (Pasolini 1988, 175) $\cdot{ }^{10}$ Edelleen on otettava huomioon myös muut äänellisen tyylittelyn mahdollisuudet. Ranskassa 1950-luvulla Robert Bresson ja Jacques Tati käyttivät ääntä poikkeuksellisen hienovaraisesti, edellinen ihmisten henkisten ulottuvuuksien, jälkimmäinen heidän arkisten toimiensa huvittavuuden kartoittamiseksi. Tavallaan konkreettiset äänet nousevat toden teolla tyylilliseksi elementiksi vasta, kun ne alkavat toimia taiteellisesti motivoituina muodostaen siten selkeän vaihtoehdon pelkästään realistisen motivaation varassa toimivalle äänen käytölle.

Musiikkiin kiinnitetään yleensä enemmän huomiota kuin muihin ääniin dialogia lukuun ottamatta. Sitä luokitellaan pääsääntöisesti ulkoelokuvallisin käsittein viitaten lähinnä musiikin tyyleihin ja lajeihin.
10 Tarkasti ottaen Pasolini lanseerasi käsitteen vapaa epäsuora näkökulmaotos. Niiden varaan rakentuva tyyli oli elokuvallinen vastine kirjalliselle tekniikalle vapaa epäsuora kerronta. Tavoitteena oli "elokuvantekijän uppoutuminen elokuvan henkilön mieleen ja ei vain hänen psykologiansa vaan myös hänen kielensä omaksuminen". 
Lisäksi eräillä melodioilla, kuten kansallislaulut ja tiettyjen liikkeiden tunnuslaulut, kuten Internationaali, on omat tunnistettavissa olevat yhteiskunnalliset funktionsa. Kaiken tämän erittely vaatii "vain" hyviä perustietoja musiikinhistoriasta. Se, miten näitä ulottuvuuksia käytetään draaman palveluksessa, on keskeinen tyylillinen ulottuvuus, joka kytkeytyy kysymyksiin, kuten toimiiko musiikki kuvattuihin tapahtumiin ja sen synnyttämiin affekteihin nähden paralleelisesti, polaroivasti vai kontrapunktisesti. ${ }^{11}$ Nämä kytkeytyvät elimellisesti musiikin asemaan joko eidiegeettisenä tai diegeettisenä elementtinä, jälkimmäisen jakaantuessa vielä objektiiviseen ja subjektiiviseen. Johtoaihetekniikan avulla musiikki voi toimia elokuvan sisäisenä referenssisysteeminä ja sen ohella jossakin määrin myös kiinnittyä todelliseen maailmaan viittaamalla aikakauteen tai sosiaaliseen ryhmään. Ehkä olennaisinta johtoaiheissa samoin kuin elokuvamusiikissa yleensäkin on kuitenkin sen affektiivinen sisältö kaikessa numeraalisuutta pakoilevuudessaan. Verbalisointiin voidaan sentään kohtuullisella harjoittelulla yltää, vaikka edellä käsiteltyjen musiikin dramaturgisten funktioiden täsmällisempi erottelu väistämättä jääkin impressioiden tasolle.

\section{Vertailtavana suomalainen elokuva}

Edellä esitetty tyylin tutkimuksen metodologia tarjoaa vertailevalle tyylitutkimukselle vahvan pohjan, joka ei rajoitu vain mitattavissa ja laskettavissa olevien suureiden vertailuun. Suppeahkon tuotannon tehneiden ohjaajien tai muiden elokuvantekijöiden kohdalla voidaan huolellisella tutkimuksella tehdä hyvinkin luotettavia yleistyksiä ja korjata aikaisempia, impressionistisempia näkemyksiä - hyvänä esimerkkinä Seppälän Cinemetrics-pohjainen analyysi Aki Kaurismäen tuotannosta (Seppälä 2015). Yleistettävyyden ongelma kasvaa huimasti tarkasteltaessa sellaisia laajoja korpuksia kuin suomalaisen tarinaelokuvan koko historia, kuten tehtiin A Transnational History of Finnish Cinema -projektissa. ${ }^{12}$ Rajallisten resurssien asettamissa puitteissa ei ollut mahdollista tehdä lähimainkaan kattavaa analyysiä muun kuin mykkäelokuvan osalta, mutta aihepiiriä työstettäessä hahmottuivat seuraavat periaatteet:

- Mitattavissa, luokiteltavissa ja laskettavissa olevien parametrien metrinen kartoitus joko kokonaisesta osakorpuksesta (mykkäelokuva) tai edustavana pidetystä otoksesta (studiokaudelta) sekä näiden tulosten vertaaminen mahdollisuuksien mukaan relevanttiin verrokkiryhmään, josta on käytettävissä vastaavaa dataa.

- Sen kartoittaminen, milloin ja missä laajuudessa enemmän tai vähemmän normittuneet elokuvalliset keinot on otettu käyttöön jossakin elokuvatuotannollisessa kontekstissa sekä kuinka omaperäisellä tavalla näitä keinoja on sovellettu verrattuna aikaisemmissa tai rinnakkaisissa konteksteissa tapahtuneisiin sovelluksiin.

- Erityisen huomiota herättävien tyylillisten ilmentymien ja niiden funktioiden kartoittaminen suhteessa kerronnallisiin, temaattisiin tai puhtaasti audiovisuaalisiin vaikutelmiin sekä näiden vertaaminen vastaaviin ilmentymiin muissa tuotannollisissa konteksteissa. Voi olla tarpeen selvittää myös se, keiden elokuvan tekoon osallistuneiden saavutuksesta on kyse - ohjaajan tai tuottajan lisäksi vaikkapa lavastajan, kuvaajan tai leikkaajan.
11 Paralleelinen musiikki tarjoaa samoja affekteja, joita tarinan sinällään voidaan ajatella tarjoavan. Polarisoiva tuo mukaan affekteja, jotka eivät ainakaan ilmeisellä tavalla ole läsnä esitetyssä tilanteessa, kontrapunktinen puolestaan selvästi erilaisia, jopa kontrastoivia affekteja.

12 A Transnational History of Finnish Cinema oli Suomen Akatemian rahoittama projekti. Sen jäsenet olivat (affiliaatiot sen mukaan, kuin ne olivat projektin toteuttamisen aikaan): Henry Bacon (projektin johtaja, Helsingin yliopisto), Pietari Kääpä (University of Stirling), Anneli Lehtisalo (Tampereen yliopisto), Jaakko Seppälä (Helsingin yliopisto), Outi Hupaniittu (Turun ja Helsingin yliopistot). Lisäksi Kimmo Laine (Turun ja Oulun yliopistot) otti osaa projektiin Turun yliopiston tutkijakollegiumin jäsenenä. Tämän artikkelin keskeisimmät huomiot ja oivallukset perustuvat olennaisessa määrin tässä ryhmässä käytyihin keskusteluihin sekä niiden myötä syntyneisiin tutkimustuloksiin. Projektin tulokset ilmestyivät paitsi lukuisissa artikkeleissa myös teoksessa Finnish Cinema: A Transnational Enterprise (2016, Lontoo: Palgrave Macmillan). 
- Kansallisesta tai sosiaalisesta kontekstista kumpuavien toposten ja muiden ulkoelokuvallisten vaikutteiden kartoittaminen suhteessa sisältöön tai audiovisuaaliseen ulkoasuun.

Relevanttien otosten tai referenssiryhmien määrittely ei aina ole yksiselitteistä, mutta näitäkään ongelmia ei pidä liioitella. Suomalaisen mykkäkauden tarinaelokuvan tuotannon volyymi on hallittavissa, ja on myös mahdollista arvioida, mistä elokuvista elokuvantekijät saivat vaikutteita. Jaakko Seppälä on tehnyt kattavan Cinemetrics-analyysin myös tästä korpuksesta (Seppälä 2016) ja osoittanut muuhun dataan perustuen, että tutkimusten mukaan relevantiksi referenssiryhmäksi kohoavat amerikkalaiset, saksalaiset ja ruotsalaiset elokuvat. Eurooppalaiset elokuvat ovat tyylin kannalta relevantein verrokkiryhmä, sillä keskimääräinen otospituus on vain vähän suurempi kuin vastaavan ajan Hollywood-elokuvissa. Tärkeä havainto on myös se, että esimerkiksi otoskestojen suhteen tämä korpus on yllättävän heterogeeninen (ibid. 68-69). Paljon on kuitenkin vielä tehtävä Cinemetricsin puitteissa jo senkin takia, että monien kysymyksenasettelujen kannalta mielenkiintoisista vertailukohteista ei ole vielä tehty kyllin kattavaa metristä analyysia. Niinpä vielä ei ole päästy tekemään vertailevaa tutkimusta esimerkiksi eri pohjoismaalaisten elokuvatuotantojen välillä.

Noin kolme vuosikymmentä kattavan studiokauden tyylillistä kehitystä on arvioitava yleistuntemuksen perusteella muodostettavien otosten tai esimerkkitapausten perusteella. Tehtävä on verraten helposti hallittavissa. Keskeisen paradigman muodostavat klassisen kerronnan eurooppalaiset muodot. Vaikutteet konkretisoituvat joskus tietotaidon liikkeissä. Esimerkiksi Suomi-Filmin 1937 palkkaamat ranskalaiset kuvaajat Marius Raichi ja Charlie Bauer jättivät jäljen myös suomalaisten kollegojensa työhön. Laajempaa vertailua kansallisten elokuvakulttuurien välillä haittaa se, että riittävän samankaltaisilla metodeilla suoritettua tyylitutkimusta ei aina ole tehty relevanttien referenssikorpusten osalta. Usein joudutaan tyytymään vertailuun yksittäisiin edustavina pidettyihin elokuviin.

Studiokausikaan ei ole tyylillisesti täysin homogeeninen, ja on mahdollista osoittaa, kuinka tietyt ohjaajat, suurin piirtein klassisen paradigman puitteissa, ovat luoneet omat persoonalliset tyylinsä. Kimmo Laine on määritellyt 1930-luvulta neljä tyyliä: 1) Tulion piktorialismi, jota luonnehtivat ennen kaikkea teatrikalistis-piktorialistinen näytteleminen ja lavastus. 2) Särkän teatrikalismi, jossa näytteleminen ja lavastus liikkuvat realistis-naturalistisen ja teatrikalistisen välillä. 3) Vaalan klassisismi, jossa näytteleminen ja valaistus ankkuroituvat selvimmin realistis-naturalistiseen. 4) Tapiovaaran kertova avantgarde, joka tasapainottelee teatrikaalisen ja tyylittelevän välillä teatrikalistisen näyttelijäntyön hyödyntäessä jopa vieraannutuskeinoja. (Laine 2016, 109.) Nämä eivät kata kaikkia tyylillisiä ilmentymiä, joita aikakauden elokuvatuotannosta voidaan löytää, mutta niiden avulla on mahdollista hahmottaa, millaisia tyylillisiä ulottuvuuksia on erotettavissa. Näitä tyylillisiä painotuksia voi eritellä motivaatioiden välisinä jännitteinä ennen kaikkea akseleilla realistis-kompositionaalinen, realistis-taiteellinen ja kompositionaalis-taiteellinen. Nämä tarjoavat edelleen vertailukohtia esimerkiksi saksalaiseen ekspressionismiin ja ranskalaiseen runolliseen realismiin, Tapiovaaran kohdalla paikoin jopa venäläiseen montaasielokuvaan.

Studiokauden jälkeen yleistysten tekeminen tulee uuden aallon myötä hyvin vaikeaksi, nousihan ihanteeksi nimenomaan elokuvataideteosten ainutlaatuisuus. Usein vaikutelma aikakauden tyylistä syntyy pikemmin- 
kin poikkeuksellisten kuin tyypillisten teosten perusteella - tämä pitänee paikkansa taiteellisten taitekohtien suhteen ylipäätään. Varsinkin elokuvan modernismissa yksittäisten ohjaajien luova panos on kuitenkin niin suuri, että on varsin vaikea määritellä selkeästi yhdistäviä tyylipiirteitä. Tyylillisen tutkimuksen kannalta on siis nostettava esille teoksia, joita voidaan pitää joko edustavina tai joiden vaikutus on ollut huomattavan suuri joko yleisön suosion, kriittisen reseption ja debatin kannalta - tai vaikka vain, koska teos on tarjonnut muille elokuvantekijöille inspiroivan mallin. Mutta kuten Laine on osoittanut, elokuvan modernismin tyylilliset vaikutteet ovat havaittavissa myös niissä elokuvan tekemisen muodoissa, jotka olivat ainakin jonkinlaista jatketta studiokaudelle ulottuen aina populaariin komediaan saakka (ibid.). Jälleen varsinkin irtiotot realistisesta motivaatiosta tarjoavat näkökulman samankaltaisuuksien ja eroavaisuuksien analyyttiselle tarkastelulle. Kokonaisuuden hahmottamista tässä vaiheessa helpottaa jälleen se, että elokuvien tuotanto tippui joksikin aikaa tutkimuksellisesti hallittavissa oleviin määriin.

Niin sanotulla toisella studiokaudella, joka pääsi toden teolla vauhtiin 1990-luvulla, tapahtuu varsin konstailematon kiinnittyminen tuttuihin lajityyppeihin. Tämä yhdistyy niin Suomen elokuvasäätiön tukemaan kuin yksittäisten alalla toimijoiden suuntautumiseen kansainvälisiin yhteistyökuvioihin, joka viimeistään on taannut tyylillisten vaikutteiden sujuvan omaksumisen - olkoonkin, että budjetit yhä rajoittavat liikkumavaraa työskentelyn monissa vaiheissa. Eri asia sitten on, että pitkän tarinaelokuvan puolella oikeastaan vain Aki Kaurismäellä on selvästi erottuva omaperäinen tyyli, joka toimii brändinä varsinkin kansainvälisillä festivaaleilla. Hänen tapauksensa ehkä mahdollistaa jopa sen, että tyylilliset vaikutteet virtaavat kerrankin myös Suomesta ulkomaille.

\section{Yhteenveto: Ehdotus kertovan elokuvan analyysiprotokollaksi}

Elokuvan tyylilliset mahdollisuudet ovat huikeat. Kuinka käytännössä systemaattisesti analysoida elokuvan tyyliä ottaen huomioon kaiken tämän moniulotteisuuden? Maksimaalisen kattavan tyylianalyysin tekemiseen voisi soveltaa seuraavaa protokollaa: ${ }^{13}$

- Oman kokemuksen erittely: miksi ja miten elokuva on tehnyt meihin

- minuun tai johonkin joukkoon katsojia - vaikutuksen?

- Miljöiden ja henkilöiden sekä heidän toimintansa psykologisten motivaatioiden tai noiden motivaatioiden problematisoinnin luonnehdinta.

- Tarvittavan tarkan synopsiksen tekeminen toiminnoista generoituvasta tarinasta.

- Dramaturgian, ennen kaikkea syuzhet/fabula-suhteen, jaksotuksen ja tarinan kuljetuksen analysoiminen. ${ }^{14}$

- Metrisen analyysin tekeminen keskeisimmistä mitattavissa ja luokiteltavissa olevista piirteistä.

- Sen eritteleminen, miten vaihtelut näiden parametrien suhteen korreloivat dramaturgiseen rakenteeseen luoden sille kognitiivisia, aistivoimaisia ja affektiivisia ulottuvuuksia.

- Muiden elokuvallisen keinojen ja niiden muodostamien kuvioiden eritteleminen ja -kuvaaminen motivaatioiden ja niiden välisten jännitteiden pohjalta.
13 Tämä esitys on paljosta velkaa Bordwell \& Thompsonin teoksessaan Film Art (1993 [1979]) esittämälle ohjeistukselle elokuvan analysoimiseksi: 1) Määrittele elokuvaa jäsentävä rakenne, sen kertova tai ei-kertova formaali järjestelmä. 2) Tunnista elokuvassa käytetyt huomiota ohjaavat tekniikat. 3) Jäljitä sovellettujen tekniikoiden kuviot läpi koko elokuvan. 4) Esitä, mitä funktioita huomioita ohjaavilla tekniikoilla on ja millaisia kuvioita ne muodostavat. (Bordwell \& Thompson 1993, 335-337.)

14 Dramaturgian voi mieltää Bordwellin tapaan tyylin kanssa rinnakkaiseksi systeemiksi (Bordwell 1985, 50). Draaman jaksottuminen on sekin tyylin kannalta keskeinen elementti, liittyyhän se olennaisesti kysymykseen rytmistä ja tarinatiedon annostelusta sekä siitä, millainen affektiivinen vaikutelma pyritään saamaan aikaan. 
- Keinojen ja kuvioiden kerronnallisten, temaattisten ja affektiivisten ulottuvuuksien analysoiminen ja tulkinta.

- Yhteenveto: kuinka tehty analyysi auttaa ymmärtämään, millaisin elokuvallisin keinoin elokuvan meissä synnyttämät vaikutelmat on saatu aikaan.

Näin perinpohjaisen analyysin tekeminen on tietysti työlästä eikä aina vastaisi tarkoitustaan. Kulloisenkin kysymyksenasettelun pohjalta on päätettävä, kuinka perusteellisesti tehtävä on mielekästä suorittaa. Eri vaiheet voivat myös painottua eri tavoin. Joskus analysointia helpottaa se, että usein jokin elokuvallinen keinovara tai keinovarojen yhdistelmä toimii, Eisensteinin termiä käyttääksemme, dominanttina eli kokonaisuutta jäsentävänä tekijänä, johon muut tekijät suhteutuvat. Joka tapauksessa tarvitaan kykyä eritellä käytettyjen keinojen relevanssia diegeesiksen konstruoinnissa, tarinan kuljettamisessa, tematiikan luomisessa ja audiovisuaalisen kokonaisvaikutelman synnyttämisessä. Tuloksen voi joka tapauksessa olettaa olevan juuri niin objektiivinen ja vertailukelpoinen kuin taideteoksen analyysiltä sopii odottaakin. Näin myös saadaan tuotettua tyylin tutkimuksen kannalta niin vertailukelpoista aineistoa kuin suinkin voi toivoa.

\section{Kirjallisuus}

Abel, Richard (2005) Encyclopedia of Early Cinema. Abingdon: Routledge.

Beach, Christopher (2015) A Hidden History of Film Style - Cinematographers, Directors, and the Collaborative Process. Oakland: California University Press.

Bordwell, David (1988 [1985]) Narration in the Fiction Film. Lontoo: Routledge.

Bordwell, David (1997) On the History of Film Style. Cambridge: Harvard University Press.

Bordwell, David (2005) Figures Traced in Light. Berkeley: University of California Press.

Bordwell, David (2008) Poetics of Cinema. New York, Lontoo: Routledge.

Bordwell, David; Staiger, Janet \& Thompson, Kristin (1985) The Classical Hollywood Cinema: Film Style and Mode of Production to 1960. Lontoo: Routledge.

Bordwell, David \& Thompson, Kristin (1993 [1979]). Film Art: An Introduction. New York: McGraw-Hill.

Chion, Michel (1990) Audio-Vision - Sound on the Screen. Toimittanut ja kääntänyt Claudia Gorbman. New York: Columbia University Press.

Ekman, Paul \& Friesen, Wallace V. (2003) Unmasking the Face. Cambridge (MA): Malor Books.

Gibbs, John \& Pye, Douglas (toim.) (2005) Style and Meaning - Studies in the Detailed Analysis Film. Manchester, New York: Manchester University Press.

Juntunen, Max (1997) Elävän kuvan sanasto. Helsinki: Edita.

Kovács, András Bálint (2007) Screening Modernism - European Art Cinema, 1950-1980. Chicago, Lontoo: The University of Chicago Press.

Kovács, András Bálint (2014) "Shot Scale Distribution: An authorial Fingerprint or Cognitive Pattern." Projections vol. 8:2, 50-70.

Laine, Kimmo (2004). "Kun isä tahtoo ... sarjakuvasovituksena eli suomalaisen studioelokuvan kolme perinnettä" Teoksessa Kimmo Laine, Matti Lukkarila \& Juha Seitajärvi (toim.) Valentin Vaala. Helsinki: Suomalaisen Kirjallisuuden Seura, 271-283.

Laine, Kimmo (2016) "Popular Modernism”. Teoksessa Henry Bacon (toim.) Finnish Cinema - A Transnational Enterprise. Lontoo: Palgrave Macmillan, 171-184.

Pasolini, Pier Paolo (1988) Heretical Empiricism. Toimittanut Louise K. Barnett, kääntäneet Ben Lawton \& Louis K. Barnett. Indianapolis: Indiana University Press. 
Russell, James A. (1994) “Is There Universal Recognition of Emotion From Facial Expression? A Review of the Cross-Cultural Studies". Psychological Bulletin vol. 115:1, 102-141.

Salt, Barry (2009 [1983]) Film Style and Technology: History and Analysis. Lontoo: Starword.

Seppälä, Jaakko (2012) Hollywood tulee Suomeen. Helsinki: Helsingin yliopisto.

Seppälä, Jaakko (2015) “On the Heterogeneity of Cinematography in the Films of Aki Kaurismäki". Projections vol. 9:2, 20-39.

Seppälä, Jaakko (2016) “Finnish Film Style in the Silent Ear". Teoksessa Henry Bacon (toim.) Finnish Cinema - A Transnational Enterprise. Lontoo: Palgrave Macmillan, 51-80.

Thompson, Kristin (1981) Breaking the Glass Armor - Neoformalist Film Analysis. Princeton: Princeton University Press.

Thompson, Kristin (1988) Eisenstein's Ivan the Terrible - A Neoformalist Analysis. Princeton: Princeton University Press. 